\title{
BMJ Open Are housing tenure and car access still associated with health? A repeat cross-sectional study of UK adults over a 13-year period
}

\author{
A Ellaway, ${ }^{1}$ L Macdonald, ${ }^{1}$ A Kearns ${ }^{2}$
}

To cite: Ellaway A, Macdonald L, Kearns A. Are housing tenure and car access still associated with health? A repeat cross-sectional study of UK adults over a 13-year period. BMJ Open 2016;6:e012268. doi:10.1136/bmjopen-2016012268

- Prepublication history and additional material is available. To view please visit the journal (http://dx.doi.org/ 10.1136/bmjopen-2016012268).

Received 14 April 2016 Revised 16 August 2016 Accepted 29 September 2016

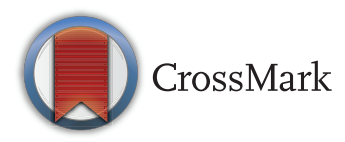

${ }^{1} \mathrm{MRC} / \mathrm{CSO}$ Social and Public Health Sciences Unit, University of Glasgow, Glasgow, UK

${ }^{2}$ Department of Urban Studies, University of Glasgow, Glasgow, UK

Correspondence to Professor A Ellaway; anne.ellaway@glasgow.ac.uk

\section{ABSTRACT}

Background: It is usually assumed that housing tenure and car access are associated with health simply because they are acting as markers for social class or income and wealth. However, previous studies conducted in the late 1990s found that these household assets were associated with health independently of social class and income. Here, we set out to examine if this is still the case.

Methods: We use data from our 2010 postal survey of a random sample of adults $(n=2092)$ in 8 local authority areas in the West of Scotland. Self-reported health measures included limiting longstanding illness (LLSI), general health over the last year and the Hospital Anxiety and Depression Scale.

Results: We found a statistically significant relationship between housing tenure and all 4 health measures, regardless of the inclusion of social class or income as controls. Compared with owner occupiers, social renters were more likely to report ill-health (controlling for social class-LLSI OR: 3.24, general health OR: 2.82 , anxiety $\eta^{2}: 0.031$, depression $\eta^{2}$ : 0.048, controlling for income-LLSI OR: 3.28 , general health OR: 2.82, anxiety $\eta^{2}: 0.033$, depression $\eta^{2}$ : $0.057)(p<0.001$ for all models). Car ownership was independently associated with depression and anxiety, with non-owners at higher risk of both (controlling for income-anxiety $\eta^{2}: 0.010$, depression $\eta^{2}: 0.023$, controlling for social class-anxiety $\eta^{2}: 0.013$, depression $\eta^{2}: 0.033$ ) ( $p<0.001$ for all models). Conclusions: Our results show that housing tenure and car ownership are still associated with health, after taking known correlates (age, sex, social class, income) into account. Further research is required to unpack some of the features of these household assets such as the quality of the dwelling and access to and use of different forms of transport to determine what health benefits or disbenefits they may be associated with in different contexts.

\section{INTRODUCTION}

A number of studies have shown that housing tenure and car access are associated with health, ${ }^{1-6}$ and they have often been

\section{Strengths and limitations of this study}

- Our study showed that home and car ownership are still associated with better health after the 2008 economic downturn.

- We conducted a repeat cross-sectional study of a random sample of residents of the same West of Scotland areas 13 years apart (1997 and 2010), using a similar postal questionnaire and thus were able to examine potential change.

- Health selection may have affected our findings in that people with poor health may be more likely to live in social rented housing as they have priority.

- In this cross-sectional study, we were unable to examine the direction of causation; for example, existing poor health might affect income or employment and thus influence ability to buy a home or a car.

viewed as indicators or proxies of social class, income or wealth rather than having any direct relationship with health. ${ }^{7}$ However, in studies conducted in the late 1990s, we showed that these assets were associated with health even after taking individual characteristics such as social class, income, age and sex into account. ${ }^{8}{ }^{9}$ Studies conducted elsewhere broadly supported our findings. ${ }^{10} 11$ However, since the late 1990s, the onset of the global economic downturn in 2008 has led to a slowdown in the UK housing market (a drop from $76 \%$ homeownership in 2001 to $65 \%$ in $2010^{12}$ ) and in other countries such as the USA where home ownership has traditionally been the preferred tenure. ${ }^{13}$ A number of studies have shown that the economic downturn was associated with a rise in mental health problems ${ }^{14-16}$ often associated with mortgage arrears. ${ }^{17} 18$ The drop in price and increase in housing repossessions (sixfold increase in the UK between 2004 and $2009^{12}$ with similar increases in the $\mathrm{USA}^{19}$ ) raise questions of whether 'the 
bloom is off the rose of homeownership'. ${ }^{20}$ There has also been a drop in car sales (new car registrations in the UK halved between 1998 and 2009, dropping from 230000 in 1998 to 110000 in $2009^{21}$ ) and rising running costs. ${ }^{22}$ These changes therefore raise questions over whether we would still find similar results to those of our studies in the late 1990s; perhaps owner-occupied homes and cars are not seen as so beneficial or as a cultural requirement following the global economic downturn and the uncertainty since. In this paper, we therefore examine whether home and car ownership are still associated with better health, and we explore these patterns separately for social class and income as these two measures have different patterns of consumption. ${ }^{23}$

\section{METHODS}

In 2010, we repeated our 1997 postal survey of a random stratified sample of adults in eight local authority areas in the West of Scotland. THAW 2010 was based on THAW 1997, a study designed to examine three objectives, first, the statistical associations between long-term morbidity and mental health and well-being on the one hand, and housing tenure and car ownership on the other (while controlling for sociodemographic and psychological characteristics); second, the role of housing quality, residential environment and use of cars, in influencing illness and psychological health; and third, the meaning of housing tenure and car ownership in people's daily lives. ${ }^{9}$ 24-30

THAW 2010 draws on respondents from the same geographical areas to our 1997 postal survey and uses a very similar postal questionnaire to the previous study. The survey included standard questions on the respondents' mental and physical health and well-being, lifestyle, housing, neighbourhood, transport, employment and finance. The majority of the items in the questionnaire were based on self-complete items used in previously conducted studies such as the West of Scotland Twenty-07: Health in the Community study. ${ }^{31}$ Our 1997 questionnaire was piloted with 200 individuals and adjustments made to the questionnaire thereafter.

In our 2010 survey, we decided to replicate our study in the same West of Scotland areas as our 1997 study due to its socially heterogeneous composition. As with our 1997 survey, our random sample of the general population was stratified to reduce selection bias ${ }^{32}$ using a geodemographic classification of neighbourhood type (using ACORN, Scottish version ${ }^{33}$ ) to ensure that all types of residential neighbourhoods (ranging from 'affluent consumers in large houses' to 'poorest council estates') were included in correct proportions.

The postal questionnaire (see online supplementary file), with three reminders (using Dillman's total design $\operatorname{method}^{34}$ ), was sent out in the autumn of 2010. We achieved a response rate of $38 \%$ (2092 completed questionnaires), from a sample of 5521 adults drawn from the electoral roll in the 8 local authority areas which make up the Glasgow and Clyde Valley Structure Plan area in the West of Scotland. The estimated population in this area in 2010 was 1763 430, and contains marked variations in social status and in health. ${ }^{35}$ Survey respondents' ages ranged from 17 to 95 years. The sociodemographic characteristics of THAW 2010 were comparable to the previous THAW 1997 study; for example, respondents' own social class was similar in THAW 1997 and THAW $2010(65 \%$ and $70 \%$ in the non-manual social class groups, respectively). Compared with the West Central Scotland population, our achieved study sample characteristics were broadly similar for sex and for age; $56 \%$ were female, and $65 \%$ were of working age (1860 years), compared with $52 \%$ and $62 \%$, respectively, within West Central Scotland. ${ }^{36}$ Within our sample, $85 \%$ of respondents had access to at least one car or van, while within the 2010 Scottish Household Survey, within West Central Scotland, $70 \%$ had access to a car (does not include van access). ${ }^{37}$

THAW 2010 was approved by the Ethics Committee of the Faculty of Law, Business and Social Sciences at the University of Glasgow. Here, we examine four domains of self-assessed health, three of which are similar to our previous paper: ${ }^{9}$ chronic, recent and mental health problems and health in general, measured, respectively, by the presence/absence of limiting longstanding illness (LLSI), perceived health over the past year as either excellent/good or fair/poor and the seven-item depression subscale of the Hospital Anxiety and Depression Scale ((HADS), higher scores on HADS indicate greater reported symptoms). ${ }^{38}$ The suite of self-assessed health measures used in the 1997 study was identified from the literature. ${ }^{8} 93039$ In the present paper, we also examined the HADS anxiety seven-item subscale as we have previously shown that some aspects of the home are associated with anxiety among social rented respondents, ${ }^{39}$ but there is a possibility that home ownership since the economic downturn may be also associated with anxiety. Social class was based on own occupation, using registrar general's sixfold classification, ${ }^{40}$ income was equivalised household income (ie, adjusted for family composition) ${ }^{41}$

We excluded respondents $(n=101)$ who reported they were economically inactive because of permanent sickness or disability (to reduce the possibility of reverse causation). We also excluded respondents who could not be categorised as owner occupier or social renter, that is, those who were privately renting $(\mathrm{N}=58)$ or those who lived in a hostel, a tied home or in relation/partner's home $(\mathrm{N}=14)$. We excluded respondents with missing data (assumed missing at random) for independent, dependent or control variables, within each model.

Logistic regression was used to explore relationships between housing tenure and car access, and LLSI and general health, each in three ways: unadjusted; adjusted for age, sex and marital status; and adjusted for age, sex, marital status and income or social class. Generalised 
linear modelling was used to investigate equivalent models for anxiety and depression scores using $\eta^{2}>$ values $\left(\eta^{2}\right.$ represents effect sizes, ie, the proportion of variance associated with main effects from ANOVA; ${ }^{42}$ effect sizes are considered 'small' if $\eta^{2}>0.01$, 'medium' if $\eta^{2} 0.06$ and 'large' if $\left.\eta^{2}>0.14^{43}\right)$. Within the models, we also investigated various interactions between tenure or car access and sex; and tenure or car access and marital status, particularly as the latter differed between owners and social renters (see table 1 ).

\section{RESULTS}

\section{Housing tenure}

We found a statistically significant relationship between all four health measures and tenure, regardless of the

\begin{tabular}{|c|c|c|}
\hline & $\begin{array}{l}\text { Owner } \\
\text { occupier } \\
\text { ( } n=1104)\end{array}$ & $\begin{array}{l}\text { Social } \\
\text { renter } \\
(n=115)\end{array}$ \\
\hline \multicolumn{3}{|l|}{ Sample characteristics } \\
\hline \multicolumn{3}{|l|}{$\operatorname{Sex}(\%)$} \\
\hline Males & 44.7 & 47.0 \\
\hline Females & 55.3 & 53.0 \\
\hline \multicolumn{3}{|l|}{ Age } \\
\hline $\begin{array}{l}\text { Mean (minimum- } \\
\text { maximum) }\end{array}$ & $51.4(17-91)$ & $52.0(20-90)$ \\
\hline \multicolumn{3}{|l|}{ Social class (\%) } \\
\hline $\begin{array}{l}\text { I/II Professional, } \\
\text { managerial and technical }\end{array}$ & 50.1 & 20.0 \\
\hline III Skilled non-manual & 25.0 & 24.3 \\
\hline III Skilled manual & 12.8 & 19.1 \\
\hline $\begin{array}{l}\text { IV/N Partly skilled and } \\
\text { unskilled }\end{array}$ & 12.1 & 36.5 \\
\hline \multicolumn{3}{|l|}{ Marital status (\%) } \\
\hline $\begin{array}{l}\text { Living with significant } \\
\text { other }\end{array}$ & 72.0 & 40.9 \\
\hline $\begin{array}{l}\text { Not living with significant } \\
\text { other }\end{array}$ & 28.0 & 59.1 \\
\hline \multicolumn{3}{|l|}{ Material assets } \\
\hline \multicolumn{3}{|l|}{ Car ownership (\%) } \\
\hline Owner & 88.7 & 58.3 \\
\hline Non-owner & 11.3 & 41.7 \\
\hline \multicolumn{3}{|l|}{ Health measures } \\
\hline \multicolumn{3}{|c|}{ Limiting longstanding illness (\%) } \\
\hline $\begin{array}{l}\text { Has limiting longstanding } \\
\text { illness }\end{array}$ & 44.6 & 78.6 \\
\hline $\begin{array}{l}\text { No limiting longstanding } \\
\text { illness }\end{array}$ & 55.4 & 21.4 \\
\hline \multicolumn{3}{|l|}{ General health (\%) } \\
\hline Excellent/good & 79.3 & 47.8 \\
\hline Fair/poor & 20.7 & 52.2 \\
\hline \multicolumn{3}{|l|}{ *HADS anxiety } \\
\hline $\begin{array}{l}\text { Mean (minimum- } \\
\text { maximum) }\end{array}$ & $6.1(0-21)$ & $8.3(0-18)$ \\
\hline \multicolumn{3}{|l|}{ *HADS depression } \\
\hline $\begin{array}{l}\text { Mean (minimum- } \\
\text { maximum) }\end{array}$ & $3.4(0-21)$ & $5.8(0-21)$ \\
\hline
\end{tabular}

inclusion of social class or income as controls (see table 2). For LLSI, the relationship was attenuated by including age, sex, marital status and social class (unadjusted OR: 3.46, adjusted OR: 3.24) or income (unadjusted OR: 3.95, adjusted: 3.28) but remained significant $(\mathrm{p}<0.001$ for all models). This was also the case for tenure and general health, controlling for the sociodemographic variables, including social class (unadjusted OR: 3.40, adjusted OR: 2.82) or income (unadjusted OR: 4.37, adjusted OR: 2.82) ( $\mathrm{p}<0.001$ for all models). The relationship between tenure and HADS anxiety was slightly strengthened by the inclusion of control variables and social class (unadjusted $\eta^{2}: 0.030$, adjusted $\eta^{2}: 0.031$ ), or income (unadjusted $\eta^{2}: 0.030$, adjusted $\eta^{2}$ : 0.033) $(p<0.001$ for all models). Similarly with tenure and HADS depression, controlling for sociodemographic variables including social class (unadjusted $\eta^{2}: 0.046$, adjusted $\left.\eta^{2}: 0.048\right)$, or income (unadjusted $\eta^{2}$ : 0.053 , adjusted $\left.\eta^{2}: 0.057\right) \quad(\mathrm{p}<0.001$ for all models $)$.

\section{Car access}

When controlling for age, sex, marital status and social class, the relationship between car access and LLSI is no longer statistically significant (unadjusted OR: 1.97 $(\mathrm{p}<0.001)$, adjusted OR: $1.27(\mathrm{p}=0.189))$ (see table 2$)$. This was also true when controlling for income (unadjusted OR: $2.03 \quad(\mathrm{p}<0.001)$, adjusted OR: 1.16 $(\mathrm{p}=0.435))$. Similar results were found for car access and general health when controlling for age, sex, marital status and social class (unadjusted OR: $2.03(\mathrm{p}<0.001)$, adjusted OR: $1.36(\mathrm{p}=0.072)$ ), or income (unadjusted OR: $2.16(p<0.001)$, adjusted OR: $1.17(p=0.384))$. On the other hand, the relationship between car access and anxiety was only slightly stronger by the inclusion of the control variables, and social class (unadjusted $\eta^{2}: 0.009$, adjusted $\eta^{2}: 0.010$ ), or income (unadjusted $\eta^{2}: 0.012$, adjusted $\left.\eta^{2}: 0.013\right) \quad(p<0.001$ for all models $)$ as controls (see table 2). Additionally, this was the case for car access and depression, when controlling for social class (unadjusted $\eta^{2}:$ 0.022, adjusted $\left.\eta^{2}: 0.023\right)$ or income (unadjusted $\eta^{2}: 0.031$, adjusted $\left.\eta^{2}: 0.033\right) \quad(p<0.001$ for all models).

\section{Interactions}

For the income-adjusted depression and tenure model, a significant interaction between tenure and sex was found $(\mathrm{p}=0.013)$; there was a significant difference in the mean depression scores between male owner occupiers (3.88) and male social renters (4.48), and an almost twofold difference between female owner occupiers (3.63) and female social renters (5.98). In both cases, social renters had higher depression scores, but the difference in scores between female tenure groups $\left(p<0.001, \eta^{2}=0.086\right)$ is greater than that of the males $\left(p<0.001, \eta^{2}=0.029\right) \quad$ (table 3). A significant interaction between tenure and marital status also exists $(p=0.014)$. Social renters have higher depression scores than owner occupiers, but the difference was $50 \%$ greater in the 
Table 2. Odds and $\eta 2$ for the relation between health measures and (a) tenure and (b) car access; unadjusted, and adjusted for age, sex and marital status, and for age, sex, marital status and social class or income.

\begin{tabular}{|c|c|c|c|c|c|c|c|c|}
\hline & \multicolumn{2}{|l|}{ LLSI } & \multicolumn{2}{|c|}{$\begin{array}{l}\text { Poor/Fair } \\
\text { general health }\end{array}$} & \multicolumn{2}{|c|}{ Depression } & \multicolumn{2}{|c|}{ Anxiety } \\
\hline & Odds & Sig. & Odds & Sig. & $\eta 2$ & Sig. & $\eta 2$ & Sig. \\
\hline \multirow{2}{*}{\multicolumn{9}{|c|}{$\begin{array}{l}\text { (a) Social Rented Tenure (owner occupier as reference) } \\
\text { Social Class }\end{array}$}} \\
\hline & & & & & & & & \\
\hline Unadjusted model & 3.46 & 0.001 & 3.40 & 0.001 & 0.046 & 0.001 & 0.030 & 0.001 \\
\hline Adjusted for age, sex, marital status & 3.50 & 0.001 & 3.17 & 0.001 & 0.047 & 0.001 & 0.031 & 0.001 \\
\hline Adjusted for age, sex, marital status, social class & 3.24 & 0.001 & 2.82 & 0.001 & 0.048 & 0.001 & 0.031 & 0.001 \\
\hline \multicolumn{9}{|l|}{ Income } \\
\hline Unadjusted model & 3.95 & 0.001 & 4.37 & 0.001 & 0.053 & 0.001 & 0.030 & 0.001 \\
\hline Adjusted for age, sex, marital status & 3.82 & 0.001 & 4.07 & 0.001 & ${ }^{*} 0.055$ & 0.001 & 0.032 & 0.001 \\
\hline Adjusted for age, sex, marital status, income & 3.28 & 0.001 & 2.82 & 0.001 & ${ }^{*} 0.057$ & 0.001 & 0.033 & 0.001 \\
\hline Number & 1305 & & 1315 & & 1316 & & 1315 & \\
\hline \multicolumn{9}{|l|}{ (b) No Car access (access to car as reference) } \\
\hline Unadjusted & 1.97 & 0.001 & 2.03 & 0.001 & 0.022 & 0.001 & 0.009 & 0.001 \\
\hline Adjusted for age, sex, marital status & 1.38 & 0.068 & 1.50 & 0.014 & 0.022 & 0.001 & 0.010 & 0.001 \\
\hline Adjusted for age, sex, marital status, social class & 1.27 & 0.189 & 1.36 & 0.072 & 0.023 & 0.001 & 0.010 & 0.001 \\
\hline \multicolumn{9}{|l|}{ Income } \\
\hline Unadjusted model & 2.03 & 0.001 & 2.16 & 0.001 & 0.031 & 0.001 & 0.012 & 0.001 \\
\hline Adjusted for age, sex, marital status & 1.38 & 0.084 & 1.59 & 0.008 & 0.031 & 0.001 & 0.013 & 0.001 \\
\hline Adjusted for age, sex, marital status, income & 1.16 & 0.435 & 1.17 & 0.384 & 0.033 & 0.001 & 0.013 & 0.001 \\
\hline Number & 1362 & & 1371 & & 1372 & & 1371 & \\
\hline
\end{tabular}

*significant interactions between tenure and sex, and tenure and marital status - see tables 3 and 4 .

case of single people (owner: 4.16 , renter: $6.13, \mathrm{p}<0.001$, $\left.\eta^{2}=0.089\right)$ than in the case of those living with a significant other (owner: 3.31, renter $4.28, \mathrm{p}<0.001, \eta^{2}=0.016$ ) (table 4).

\section{DISCUSSION}

In our 2010 study of a random sample of adults in the West of Scotland, we found that household assets such as owning one's home or car are still associated with some of the health we observed in our earlier study in the late 1990s. Other studies broadly support our findings; ${ }^{44}$ and a study of national health surveys for 10 European countries found that housing tenure was associated with better health in some countries (Great Britain and the Netherlands) but not all, suggesting that the meaning and importance of tenure is context-specific. ${ }^{45}$ The importance of context is reflected in an Australian study which found that while mental health varied by tenure, home ownership was no longer associated with better health once other sociodemographic characteristics were taken into account. ${ }^{46}$

There are several plausible reasons why housing tenure might be associated with the health outcomes we have examined. Social housing in the UK is frequently provided in the form of estates which often have associations with particular, historical forms of employment which affect long-term health. Estates are also
Table 3 Tenure and depression (sex $\times$ tenure) (controls: age, and income)

\begin{tabular}{ll}
\hline & Mean depression score \\
\hline Male & \\
Owner occupier (523) & 3.88 \\
Social renter (65) & 4.48 \\
& $\left(\right.$ sig. $\left.=0.001, \eta^{2}=0.029\right)$ \\
Female & 3.63 \\
Owner occupier (651) & 5.98 \\
Social renter (77) & $\left(\right.$ sig. $\left.=0.001, \eta^{2}=0.086\right)$ \\
\hline
\end{tabular}

Table 4 Tenure and depression (marital statusxtenure) (controls: age, sex, and income)

\begin{tabular}{ll}
\hline & Mean depression score \\
\hline Single & \\
Owner occupier (332) & 4.16 \\
Social renter (85) & 6.13 \\
& $\left(\right.$ sig. $\left.=0.001, \eta^{2}=0.089\right)$ \\
Lives with sig. other & 3.31 \\
Owner occupier (842) & 4.28 \\
Social renter (57) & $\left(\right.$ sig. $\left.=0.001, \eta^{2}=0.016\right)$ \\
\hline
\end{tabular}


considered to have distinct cultures ${ }^{47}$ and established norms, etc, which may affect health behaviours (and in turn physical health) and psychosocial health. Behaviours on social housing estates can also manifest as antisocial behaviour which causes residents a great deal of anxiety, so that concerns about disturbance, potential threats and safety could underlie some of the greater anxiety felt by social renters. The Scottish Household Survey has consistently found that social renters report various types of antisocial behaviour problems 2-3 times more often than owner occupiers, and that those people living in the most deprived areas feel far less safe in their neighbourhood than others. ${ }^{48}$

There are two possible reasons why social renting might be associated with higher levels of depression. First, environmental quality (eg, street cleanliness) is often worse in social housing areas, due to poor design as well as lower levels of environmental maintenance by service providers relative to need in deprived areas. ${ }^{49}$ Other research with residents in such areas has shown a strong association between neighbourhood quality (eg, litter and graffiti) and mental well-being. ${ }^{50}$ Second, relative deprivation ${ }^{51}$ may play a role, so that a psychosocial pathway operates between inequality and mental health $^{52}$ in that those people without assets such as their own homes or cars feel disadvantaged in a statusoriented society ${ }^{53}$ which may in turn be reflected in higher depression scores among social renters and non-car owners. Past research has shown associations between the perceived relative quality of the home and self-esteem ${ }^{25}$ and that mental well-being is higher where people feel they live in desirable homes and in neighbourhoods that people rate highly. ${ }^{54}$ It is of interest to note that our findings that home ownership is associated with better health were in turn patterned by the route to home ownership as the differences between tenure type and health were smaller among those who had bought their homes under the Right to Buy (RTB) scheme (data not shown). The RTB scheme is a UK policy whereby public sector tenants had the right to purchase their homes at heavily discounted prices. The scheme ended on 31 July 2016 in Scotland but continues elsewhere in the UK. Many be of the dwellings purchased under this scheme tended to of better quality and in more popular social housing areas, leading to residualisation whereby the majority of housing stock left for social renting was of poorer quality and in less popular neighbourhoods. ${ }^{55}$ It is also of interest to note that other studies have found that by including that housing wealth (assessed by house value) may shed more light on the possible mechanisms linking tenure and health than tenure alone (see, eg, Connolly et $a l \mathrm{~s}^{56}$ study in Northern Ireland which linked census data on health with objective data on house values obtained from the national assessor).

Similar psychosocial mechanisms may operate in respect of cars, and again we would expect the effects to be less than those of housing tenure, as shown in the depression and anxiety results reported here.
Interestingly, the association between car access and these psychosocial measures is stronger than in our 1997 survey; this may reflect the growing importance of car ownership for psychosocial health and everyday life $\mathrm{e}^{57}$ since the late 1990s. ${ }^{58} 59$ The association between housing tenure and LLSI when controlling for social class was also stronger (an almost twofold increase in the odds of reporting) in our 2010 survey than our 1997 study. This may be a reflection of the composition of our achieved sample in 2010 as it contained a larger proportion of older adults than our 1997 sample, Although we controlled for age in our models, it may be that other unmeasured variables may play a part.

We studied residents of the same areas 13 years apart (1997 and 2010) using a similar questionnaire and thus were able to examine potential change after the economic downturn. In accord with downward trends in survey participation ${ }^{60-62}$ and response rates in deprived areas, ${ }^{63}$ we achieved a lower response rate $(38 \%)$ compared with our 1997 study $(50 \%)$. However, the response rate for each question, considered another measure of the survey's response rate, ${ }^{64}$ was at least $95 \%$ for more than $90 \%$ of the 78 -item questionnaire. Our sample comprises a largely urban sample and it may be that we would have found different results in a more rural population such as the highlands of Scotland ${ }^{65}$ and rural areas elsewhere in the $\mathrm{UK}^{66}{ }^{67}$ where car ownership is a necessity. Our findings that housing tenure and car ownership are associated with health may be subject to residual confounding, in that there are likely to be unmeasured socioeconomic circumstances that affect these associations, particularly those measured across the life course. ${ }^{68}$ Health selection may also play a part in that individuals in poor health may be 'sorted' into social housing due to the UK priority points system. ${ }^{69}$ Moreover, in an attempt to reduce reverse causation in our analysis, we excluded those respondents who reported they were economically inactive because of permanent sickness or disability; however, it is still possible that poor health lowers earnings and in turn the likelihood of being able to buy a home and/or a car. However, in a cross-sectional study like ours, it is not possible to disentangle these factors.

In conclusion, given our findings that housing tenure and car ownership are still independently associated with health, after taking known correlates such as age, social class, income and gender into account, it still seems therefore that it is important to unpack some of the features of these household assets, such as the quality of the dwelling and access to and use of different forms of transport, to determine what health benefits or disbenefits they may currently be associated with in the UK and in different contexts.

Acknowledgements The authors are grateful to the study participants for their time and effort in completing the questionnaires. Thanks are also due to the MRC/CSO Survey office for their invaluable support in conducting the postal survey. 
Contributors All authors contributed to the study design. LM undertook data analysis. All authors contributed to the interpretation of the data. AE wrote the first draft of the paper and LM and AK read the draft and provided critical comments. All authors read and approved the final draft of the paper.

Funding AE and LM are supported by the UK Medical Research Council Neighbourhoods and Communities Programme (MC_UU_12017/10).

Competing interests None declared.

Patient consent Obtained.

Ethics approval THAW 2010 was approved by the Ethics Committee of the Faculty of Law, Business and Social Sciences at the University of Glasgow.

Provenance and peer review Not commissioned; externally peer reviewed.

Data sharing statement We are committed to maximising the use of the Transport Housing and Wellbeing study data to advance knowledge to improve human health and welcome proposals for collaborative projects and data sharing. Our data sharing policy aims to balance making data as widely and freely available as possible with safeguarding the privacy of participants, protecting confidential data and maintaining the reputation of the study. No additional data available.

Open Access This is an Open Access article distributed in accordance with the terms of the Creative Commons Attribution (CC BY 4.0) license, which permits others to distribute, remix, adapt and build upon this work, for commercial use, provided the original work is properly cited. See: http:/ creativecommons.org/licenses/by/4.0/

\section{REFERENCES}

1. Filakti H, Fox J. Differences in mortality by housing tenure and by car access from the Longitudinal Study. Popul Trends 1995;81:27-30.

2. Gould MI, Jones K. Analyzing perceived limiting long-term illness using UK census microdata. Soc Sci Med 1996;42:857-69.

3. Haynes R. Inequalities in health and health service use: evidence from the General Household Survey. Soc Sci Med 1991;33:361-8.

4. Lewis $G$, Booth M. Regional differences in mental health in Great Britain. J Epidemiol Community Health 1992;46:608-11.

5. Rodgers B. Socio-economic status, employment and neurosis. Soc Psychiatry Psychiatr Epidemiol 1991;26:104-14.

6. Woodward M, Shewry MC, Smith WC, et al. Social status and coronary heart disease; results from the Scottish heart health Study. Prev Med 1992;21:136-48.

7. Carr-Hill R, Sheldon T, Thunhurst $C$. The politics of deprivation indices and health. In: Spencer $\mathrm{N}$, Janes $\mathrm{H}$, eds. Uses and abuses of deprivation indices. Warwick: University of Warwick, 1992:1-76.

8. Macintyre S, Ellaway A, Der G, et al. Do housing tenure and car access predict health because they are simply markers of income or self esteem? A Scottish study. J Epidemiol Community Health 1998;52:657-64.

9. Macintyre S, Hiscock R, Kearns A, et al. Housing tenure and car access: further exploration of the nature of their relations with health in a UK setting. J Epidemiol Community Health 2001;55:330-1.

10. Laaksonen M, Markikainen P, Nihtilä E, et al. Home ownership and mortality: a register-based follow-up study of 3000,000 Finns. $J$ Epidemiol Community Health 2008;62:293-7.

11. Pollack CE, von dem Knesebeck O, Siegrist J. Housing and health in Germany. J Epidemiol Community Health 2004;58:216-22.

12. Office of National Statistics (2015) Housing and Homeownership in the UK, http://visual.ons.gov.uk/uk-perspectives-housing-and-homeownership-in-theuk

13. Belsky ES. The dream lives on: the future of homeownership in America. Boston: Joint Center for Housing Studies, Harvard University, 2013.

14. Karanikolos M, Mladovsky P, Cylus J, et al. Financial crisis, austerity, and health in Europe. Lancet 2013;381:1323-31.

15. Katikireddi SV, Niedzwiedz CL, Popham F. Trends in population mental health before and after the 2008 recession: a repeat cross-sectional analysis of the 1991-2010 Health Surveys of England. BMJ Open 2012;2.

16. Roca M, Gili M, Garcia-Campayo J, et al. Economic crisis and mental health in Spain. Lancet 2013;382:1977-8.

17. Pevalin DJ. Housing repossessions, evictions and common mental illness in the UK: results from a household panel study. J Epidemiol Community Health 2009;63:949-51.
18. Tsai AC. Home foreclosure, health, and mental health: a systematic review of individual, aggregate, and contextual associations. PLoS ONE 2015;10:e0123182.

19. Joint Centre for Housing Studies. The state of the nation's housing. Boston, 2016

20. Rohe W, Lindblad M. Reexamining the social benefits of homeownership after the housing crisis. Boston: Joint Center for Housing Studies of Harvard University, 2013.

21. Society Motor Manufacturers and Traders. SMMT new car registrations, 2016. www.smmt.co.uk

22. The Automobile Association. Car running costs. http://www.theaa. com/motoring_advice/motoring_costs.html

23. Mihic M, Culina G. Buying behavior and consumption: social class versus income. Management 2006;11:77-92.

24. Ellaway A, Hiscock R, Macintyre S, et al. In the driving seat: psychosocial benefits from private motor vehicle transport compared to public transport. Transportation Res 2003;6:217-31.

25. Ellaway A, McKay L, Macintyre S, et al. Are social comparisons of homes and cars related to psychosocial health? Int J Epidemiol 2004;33:1065-71.

26. Hiscock R, Kearns A, Macintyre S, et al. Ontological security and psychosocial benefits from the home: qualitative evidence on issues of tenure. Housing Theory Soc 2001;18:50-66.

27. Hiscock R, Macintyre S, Kearns A, et al. Means of transport and ontological security: do cars provide psycho-social benefits to their users? Transportation 2002;7:119-35.

28. Hiscock R, Macintyre S, Kearns A, et al. Residents and residence: factors predicting the health disadvantage of social renters compared to owner-occupiers. J Soc Issues 2003;59:527-46.

29. Kearns A, Hiscock R, Ellaway A, et al. Beyond four walls. The psycho-social benefits of home: evidence from West Scotland. Housing Stud 2000;15:387-410.

30. Macintyre S, Ellaway A, Hiscock R, et al. What features of the home and the area might help to explain observed relationships between housing tenure and health? Evidence from the west of Scotland. Health Place 2003;9:207-18.

31. Benzeval M, Der G, Ellaway A, et al. Cohort profile: west of Scotland twenty-07 study: health in the community. Int J Epidemiol 2009;38:1215-23.

32. Sedgwick P. Bias in observational study designs: cross sectional studies. BMJ 2015;350:h1286.

33. CACI. A Classification of Residential Neighbourhoods, 2010. http:// acorn.caci.co.uk/downloads/Acorn-User-guide.pdf

34. Dillman D. Mail and telephone surveys; the total design method. New York: John Wiley, 1978.

35. Audit Scotland. Health inequalities in Scotland. Edinburgh: Audit Scotland, 2012

36. General Registrar Office. Edinburgh: GROS Mid-2010 Population Estimates Scotland. http://www.nrscotland.gov.uk/statistics-and-data/ statistics/statistics-by-theme/population/population-estimates/midyear-population-estimates

37. The Scottish Government. Scottish Household Survey-Annual Report 2009/2010—LA Tables. http://www.gov.scot/Topics/ Statistics/16002/LATables2009-2010

38. Zigmond A, Snaith R. The hospital anxiety and depression scale. Acta Psychiatr Scand 1983;67:361-70.

39. Ellaway A, Macintyre S. Does housing tenure predict health in the UK because it exposes people to different levels of housing related hazards in the home or its surroundings? Health Place 1998;4:141-50.

40. Office of Population Censuses and Surveys. OPCS standard occupational classification. London: HMSO, 1991.

41. Goodman A, Webb S. For richer for poorer. The changing distribution of income in the UK 1961-91. London: Institute of Fiscal Studies, 1994

42. Tabachnick BG, Fidell LS. Using multivariate statistics. 5th edn. New Jersey: Pearson Allyn \& Bacon, 2001.

43. Cohen J. Statistical power analysis for the behavioral sciences. 2nd edn. Hillsdale, NJ: Erlbaum, 1988.

44. Windle GS, Burholt V, Edwards RT. Housing related difficulties, housing tenure and variations in health status: evidence from older people in Wales. Health Place 2006;12:267-78.

45. Dalstra JA, Kunst AE, Mackenbach JP. A comparative appraisal of the relationship of education, income and housing tenure with less than good health among the elderly in Europe. Soc Sci Med 2006;62:2046-60.

46. Baker E, Bentley R, Mason K. The mental health effects of housing tenure: causal or compositional? Urban Stud 2013:50:426-42.

47. Hanley L. Estates: an intimate history: Granta, 2007.

48. Scottish Government. Scotland's People. Annual report: results from 2011 Scottish Household Survey. Edinburgh: The Scottish Government, 2012. 
49. Hastings A. Poor neighbourhoods and poor services: evidence on the 'Rationing' of environmental service provision to deprived neighbourhoods. Urban Stud 2009;46:2907-27.

50. Bond L, Kearns A, Mason P, et al. Exploring the relationships between housing, neighbourhoods and mental wellbeing for residents of deprived areas. BMC Public Health 2012;12:48.

51. Runciman W. Relative deprivation and social justice: a study of attitudes to social inequality in 20th Century England. London: Routledge Kegan Paul, 1966.

52. Kawachi I, Kennedy BP. Income inequality and health: pathways and mechanisms. Health Serv Res 1999;34(Pt 2):215-27.

53. de Botton A. Status anxiety. London: Hamish Hamilton, 2004.

54. Kearns A, Whitley E, Bond L, et al. The psychosocial pathway to mental well-being at the local level: investigating the effects of perceived relative position in a deprived area context. J Epidemiol Community Health 2013;67:87-94.

55. Murie A. The Right to Buy?: selling off public and social housing. Bristol: Policy Press, 2016.

56. Connolly S, O'Reilly D, Rosato M. House value as an indicator of cumulative wealth is strongly related to morbidity and mortality risk in older people: a census-based cross-sectional and longitudinal study. Int $J$ Epidemiol 2010;39:383-91.

57. Lucas K, Jones P. The car in British society. London: RAC Foundation, 2009

58. Goodman A, Guell C, Panter J, et al. Healthy travel and the socio-economic structure of car commuting in Cambridge, UK: a mixed-methods analysis. Soc Sci Med 2012;74:1929-38.
59. Morris EA, Guerra E. Mood and mode: does how we travel affect how we feel? Transportation 2015;42:25-43.

60. Curtin R, Presser S, Singer E. Changes in telephone survey nonresponse over the past quarter century. Public Opinion $Q$ 2005;69:87-98.

61. Nicolaas G. The use of incentives to motivate hard to get households in National Travel Surveys. Survey Methods Newsletter 2004;22:19-27.

62. Hox J, De Leeuw E. A comparison of nonresponse in mail, telephone, and face-to-face surveys. Qual Quant 1994;28:329-44.

63. Choudhury Y, Hussain I, Parsons S, et al. Methodological challenges and approaches to improving response rates in population surveys in areas of extreme deprivation. Prim Health Care Res Dev 2012;13:211-18.

64. Statistics Canada. Canadian Community Health Survey (CCHS) 2011 sampling design and collection. Statistics Canada, 2011.

65. Gray D, Shaw J, Farrington JH. Community transport, social capital and social exclusion in rural areas. Area 2006;38:89-98.

66. Christie SM, Fone DL. Does car ownership reflect socio-economic disadvantage in rural areas? A cross-sectional geographical study in Wales, UK. Public Health 2003;117:112-16.

67. Ward M, Somerville P, Bosworth G. 'Now without my car I don't know what l'd do': the transportation needs of older people in rural Lincolnshire. Local Economy 2014;28:553-6.

68. Galobardes B, Shaw M, Lawlor DA, et al. Indicators of socioeconomic position (part 1). J Epidemiol Community Health 2006;60:7-12.

69. Smith S. Explaining the link between housing and health: all or nothing? Housing Theory Soc 2012;29:40-6. 